\title{
PENINGKATAN AKTIVITAS DAN HASIL BELAJAR FISIKA MATERI KELISTRIKAN MELALUI PEMANFAATAN ALAT PERAGA KIT
}

\begin{abstract}
Sumaryatun
Abstrak

Tujuan penelitian ini adalah untuk meningkatkan aktivitas dan hasil belajar fisika materi kelistrikan melalui pemanfaatan alat peraga KIT bagi peserta didik kelas IXF SMP Negeri 1 Kaliwungu Kudus pada semester 1 tahun 2012/2013. Penelitian ini dilakukan dengan mengambil subyek peserta didik kelas IXF SMP Negeri 1 Kaliwungu Kudus sejumlah 33 anak terdiri dari 15 anak laki-laki dan 18 anak perempuan, dimana peneliti sebagai guru IPA (fisika) pada kelas tersebut. Penelitian ini dilakukan selama 5 bulan dari bulan September 2012 sampai bulan Januari 2013.

Metode yang digunakan dalam penelitian ini adalah penelitian tindakan kelas yang terdiri dari II siklus, masing-masing siklus terdiri dari 4 tahapan yaitu perencanan (planning), pelaksanaan (acting), pengamatan (observing) dan refleksi (reflecting). Pada siklus I tindakan yang dilakukan dengan memanfaatkan alat peraga KIT kelompok besar, sedangkan pada siklus II tindakan yang dilakukan dengan memanfaatkan alat peraga KIT kelompok kecil.
\end{abstract}

Hasil penelitan menunjukkan bahwa secara teoritik dan empirik melalui pemanfaatan alat peraga KIT dapat meningkatkan aktivitas dan hasil belajar fisika materi kelistrikan bagi peserta didik kelas IXF SMP Negeri 1 Kaliwungu Kudus pada semester 1 tahun 2012/2013. Peningkatan aktivitas belajar fisika sebesar 48,5\% dari kondisi awal 30,3\% menjadi 66,7\% pada siklus I dan 78,8\% pada akhir siklus II. Sedangkan Peningkatan hasil belajar fisika sebesar 39,16\% dari kondisi awal 36,36\% (tuntas KKM=12, rata-rata $=64,85$ ) menjadi $60,61 \%$ (tuntas $\mathrm{KKM}=20$, rata-rata $=71,51$ ) pada siklus I dan 75,76\% (tuntas KKM= 25, rata-rata=74,85) pada akhir siklus II.

Kata kunci: Aktivitas belajar, Hasil belajar, Pemanfaatan alat peraga KIT. 


\section{Latar Belakang Masalah}

SMP Negeri 1 Kaliwungu Kudus adalah Sekolah Standar Nasional yang dalam proses belajar mengajarnya telah banyak didukung oleh sarana prasarana seperti laboratorium, perpustakaan, ruang multi media, kelas yang telah dilengkapi LCD proyektor, buku paket, alat peraga pendidikan dan lain-lain, ternyata tidak menjamin aktivitas dan hasil belajar peserta didik yang baik. Rendahnya aktivitas belajar peserta didik terlihat di kelas IXF, yaitu saat peneliti mengajar di kelas tersebut dijumpai peserta didik yang bicara sendiri dengan temannya, tidak fokus pada peneliti yang sedang menerangkan bahkan ada yang mengantuk. Sedangkan rendahnya hasil belajar peserta didik di kelas IXF terlihat pada hasil ulangan Kompetensi Dasar (KD) 3.1 tentang listrik statis dengan jumlah 33 peserta didik memperoleh rata-rata nilai 64,85 dengan 12 peserta didik $(36,6 \%)$ yang tuntas dan 21 peserta didik $(63,4 \%)$ yang tidak tuntas. Ketuntasan Belajar Minimal (KKM) tahun pelajaran 2012/2013 yang telah ditetapkan oleh sekolah adalah 75 tidak tercapai. Hal ini menunjukkan bahwa hasil belajar peserta didik masih rendah.

Kesulitan dalam belajar fisika pada peserta didik salah satu faktor penyebabnya ditimbulkan oleh guru karena biasanya pelajaran fisika disajikan kepada peserta didik dalam konsep-konsep yang begitu abstrak dan kompleks, sehingga menimbulkan kesulitan yang serius (Nathan Hindarto, 1995). Peserta didik cenderung belajar hapalan, pengalaman belajar yang ditemui peserta didik ini akan membentuk persepsi tentang pelajaran fisika yang tidak menyenangkan. Berpegang pada kenyataan tersebut, salah satu gagasan Einstein yang mungkin bisa memberikan alternatif pemecahan masalah menyatakan bahwa dalam belajar fisika kita harus berusaha menguraikan serta menjelaskan hukum-hukum alam dan kejadiankejadian dalam alam dengan gambaran menurut pemikiran manusia (Holton dalam Druxes, 1995).

Gambaran menurut pemikiran manusia dapat dituangkan dalam suatu media atau alat peraga sederhana untuk menjelaskan konsep-konsep fisika, mengingat peserta didik pada umumnya dan khususnya usia SMP lebih tertarik pada benda-benda yang diamati secara langsung (kongkret), daripada hal-hal yang bersifat abstrak. 
Hal ini yang menyebabkan pelajaran fisika disenangi peserta didik karena guru sering menggunakan peragaan atau praktikum. Jika peserta didik sudah menyenangi pelajaran fisika maka diharapkan aktifitas dan hasil belajarnya pun meningkat. Oleh karena itu agar aktifitas dan hasil belajar di kelas IXF meningkat, maka peneliti perlu menggunakan alat peraga. Alat peraga yang dibutuhkan adalah KIT listrik yang dapat memudahkan peserta didik memahami konsep tentang kelistrikkan yang kongkret bukan abstrak lagi.

Salah satu alat peraga yang digunakan dalam proses belajar mengajar pada tingkat SMP adalah KIT fisika yaitu seperangkat alat peraga fisika bantuan pemerintah. Adanya pembagian alat peraga KIT fisika dari pemerintah belum dimanfaatkan secara optimal oleh guru. Kenyataan yang dihadapi peneliti di SMP Negeri 1 Kaliwungu bahwa alat peraga KIT yang ada masih dibiarkan bertumpuk dengan rapi tidak pernah digunakan secara maksimal oleh guru. Hal ini sangat disayangkan mengingat alat peraga sangat berperan dalam penanaman konsep fisika bagi peserta didik. Jika tidak menggunakan alat peraga pemahaman konsep pada peserta didik masih abstrak sehingga hasil belajarnya pun rendah sedangkan jika menggunakan alat peraga maka pemahaman konsep pada peserta didik pun kongkret sehingga hasil belajar akan tinggi.

Berdasarkan latar belakang, maka rumusan masalah sebagai berikut: (1) Apakah melalui pemanfaatan alat peraga KIT listrik dapat meningkatkan aktivitas belajar fisika materi kelistrikan bagi peserta didik kelas IXF SMP Negeri 1 Kaliwungu Kudus pada semester 1 tahun pelajaran 2012/2013?, dan (2) Apakah melalui pemanfaatan alat peraga KIT listrik dapat meningkatkan hasil belajar fisika materi kelistrikan bagi peserta didik kelas IXF SMP Negeri 1 Kaliwungu Kudus pada semester 1 tahun pelajaran 2012/2013?

Sedangkan tujuan penelitian ini bertujuan untuk meningkatkan aktivitas dan hasil belajar peserta didik kelas IXF SMP Negeri 1 Kaliwungu Kudus pada semester 1 tahun pelajaran 2012/2013 melalui pemanfaatan alat peraga KIT.

\section{Kerangka Berpikir}

Pada kondisi awal guru belum memanfaatkan alat peraga 
KIT listrik sehingga aktivitas dan hasil belajar fisika rendah. Supaya aktivitas dan hasil belajar fisika materi kelistrikan meningkat maka diperlukan adanya tindakan yang dilakukan guru, yaitu guru memanfaatkan alat peraga KIT listrik. Siklus pertama adalah pemanfaatan alat peraga KIT listrik kelompok besar dengan materi kelistrikan pada kompetensi dasar 3.2 listrik dinamis, dilanjutkan dengan siklus kedua adalah pemanfaatan alat peraga KIT listrik kelompok kecil dengan materi kelistrikan pada kompetensi dasar 3.3 sumber tegangan arus searah.

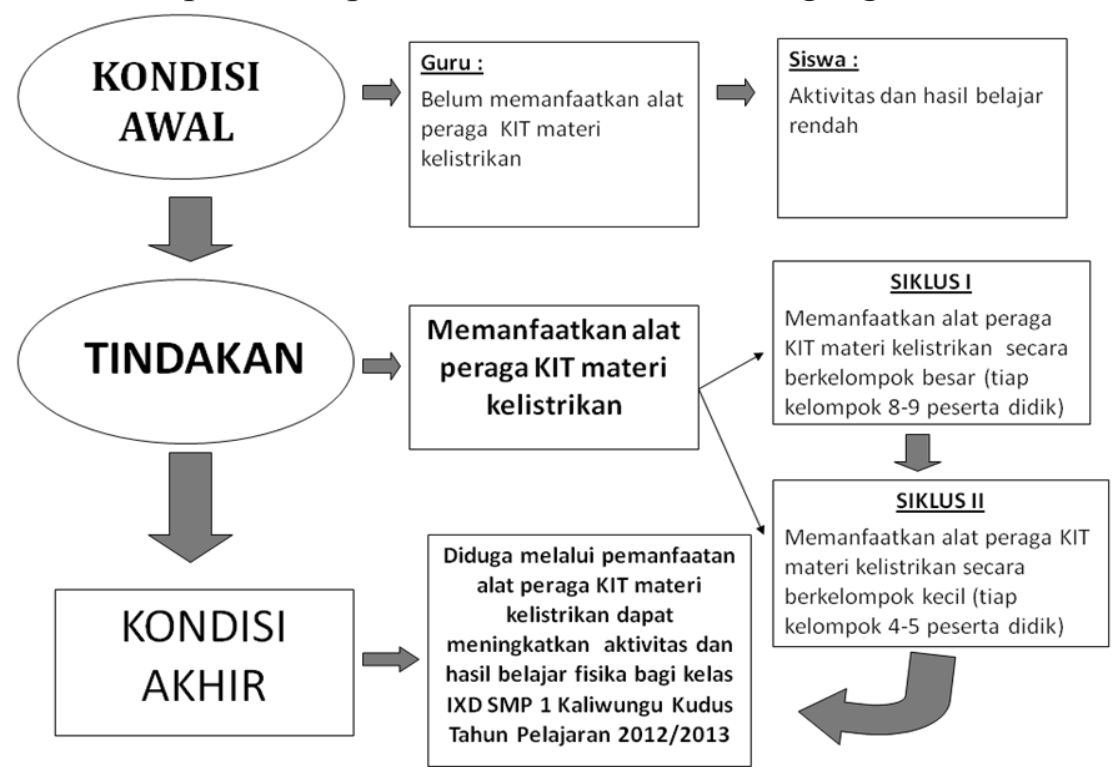

\section{Gambar 1}

\section{Kerangka berpikir}

\section{Metodologi Penelitian}

\section{Setting Penelitian}

Subjek dalam penelitian ini adalah seluruh peserta didik kelas IXF SMP Negeri 1 Kaliwungu Kudus pada semester 1 tahun pelajaran 2012/2013 yang berjumlah 33 peserta didik terdiri dari 15 anak laki-laki dan 18 anak perempuan. Objek dalam penelitian ini adalah aktivitas belajar fisika, hasil belajar fisika dan pemanfaatan 
alat peraga KIT materi kelistrikan pada kompetensi dasar listrik dinamis dan sumber tegangan arus searah. Waktu penelitian ini dilakukan selama 5 bulan, yaitu dari bulan September 2012 sampai bulan Januari 2013. Sedangkan tempat penelitian ini adalah kelas IXF SMP Negeri 1 Kaliwungu Kudus pada semester 1 tahun pelajaran 2012/2013.

\section{Data dan Sumber Data}

Teknik pengumpulan data yang digunakan antara lain: (1) Teknik dokumentasi digunakan untuk mencari data kondisi awal aktivitas belajar dan hasil belajar fisika peserta didik, (2) Teknik pengamatan atau observasi digunakan untuk memperoleh data aktivitas belajar fisika peserta didik pada siklus I dan II, dan (3) Teknik tes tertulis digunakan untuk memperoleh data hasil belajar fisika peserta didik pada siklus I dan II.

Analisis Data diperoleh dari: (1) Analisis data aktivitas belajar fisika menggunakan teknik deskriptif komparatif dilanjutkan dengan refleksi. (2) Analisis data hasil belajar fisika menggunakan teknik deskriptif komparatif dilanjutkan dengan refleksi.

Indikator kinerja dalam penelitian ini dilihat dari peningkatan aktivitas dan hasil belajar fisika melalui pembelajaran dengan memanfaatkan alat peraga KIT materi kelistrikan. Indikator keberhasilan direfleksikan dengan: (1) 70\% peserta didik mencapai rata-rata skor aktivitas belajar lebih besar dari 3,00 (kualifikasi baik), (2) $70 \%$ peserta didik memperoleh nilai hasil belajar $\geq 75$.

\section{Prosedur Tindakan}

Penelitian ini dilakukan menggunakan metode Penelitian Tindakan Kelas yang terdiri dari 2 siklus. Tindakan dalam setiap siklus saling berkaitan erat. Pada siklus I pembelajaran dilakukan dengan memanfaatkan alat peraga KIT kelompok besar, sedangkan pada siklus II dengan memanfaatkan alat peraga KIT kelompok kecil. Siklus I dan II berlangsung pada 8 pertemuan (12 jam pelajaran). Variabel yang diteliti adalah pemanfaatan alat peraga KIT sebagai penyebab serta aktivitas belajar dan hasil belajar sebagai akibat. 
Tahapan-tahapan dalam tiap siklus terdiri dari: (1) Membuat perencanaan tindakan (planning); (2) Melaksanakan tindakan sesuai yang direncanakan (acting); (3) Melaksanakan pengamatan terhadap tindakan yang dilaksanakan (observing); (4) Menganalisis dengan deskriptif komparatif dilanjutkan dengan refleksi terhadap hasil pengamatan tindakan (reflecting).

Langkah-langkah tersebut dapat digambarkan sebagai berikut:

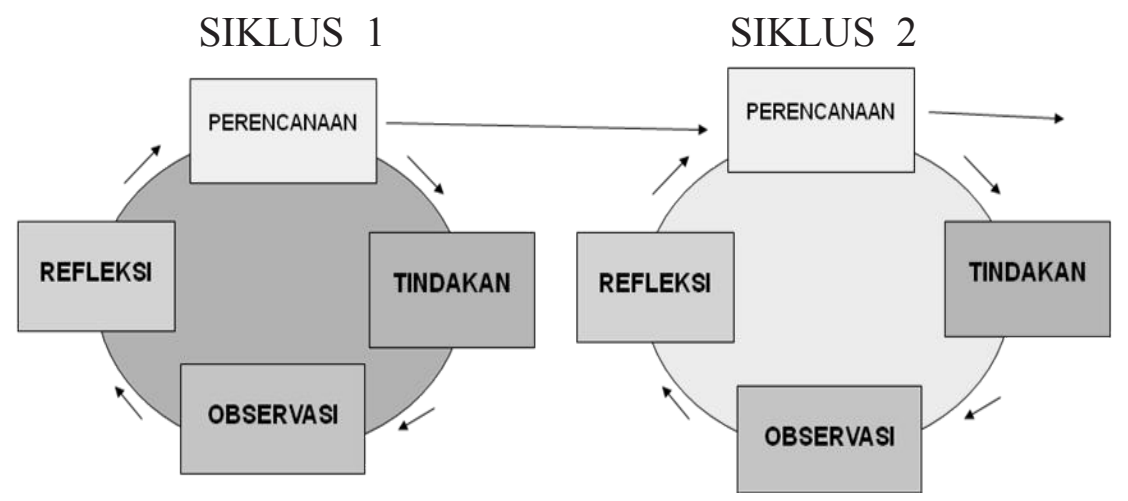

Gambar 2

Pelaksanaan tindakan dalam 2 siklus

\section{Hasil Tindakan}

\section{Deskripsi Data Kondisi Awal}

Dalam kegiatan belajar mengajar, disaat peneliti menjelaskan peserta didik tampak memperhatikan dengan seksama dan tenang, tetapi saat peneliti memberi tugas untuk dikerjakan kecenderungan peserta didik pasif dan menunggu temannya untuk mengerjakan tugas. Beberapa peserta didik bahkan tidak mengerjakan dan memilih bercakap-cakap dengan temannya. Saat ditanya oleh peneliti, mereka mengatakan tidak bisa tanpa mau berusaha. Dalam diskusi kelompok pun peserta didik cenderung diam, pasif, dan individualis.

Aktivitas belajar pada kondisi awal diamati sebelum dilakukan tindakan sehingga data kondisi awal harus diambil pada materi sebelumnya. Pengamatan dilakukan pada aspek diskusi, kerjasama, dan keaktifan dalam pembelajaran materi listrik statis. Peneliti mengambil data catatan personal aktivitas belajar peserta didik saat be- 
lajar materi listrik statis. Materi listrik statis merupakan kompetensi dasar pertama (KD 3.1) yang diajarkan di awal semester 1 pada kelas IX sesuai dengan standar kompetensi yang ke-3 yaitu tentang konsep kelistrikan dan penerapannya dalam kehidupan sehari-hari. Hasil pengamatan menunjukkan hanya terdapat 10 peserta didik berkualifikasi baik atau 30,3\% di dalam aktivitas belajarnya.

Hasil belajar pada kondisi awal diperoleh dari nilai ulangan harian peserta didik pada kompetensi dasar 3.1 yaitu: mendeskripsikan muatan listrik untuk memahami gejala-gejala listrik statis serta kaitannya dalam kehidupan sehari-hari. Hasil ulangan harian materi listrik statis dengan KKM 75 menunjukkan rata-rata 64,85 dengan rincian 12 siswa (36,36 \%) tuntas dan 21 siswa (63,64\%) tidak tuntas. Hal ini menunjukkan bahwa hasil belajar IPA (fisika) peserta didik masih rendah.

\section{Deskripsi Data Siklus I}

Pada siklus I pembelajaran menggunakan KIT listrik dinamis dengan kelompok besar yaitu dalam satu kelas dibagi 4 kelompok besar yang masing-masing kelompoknya terdiri dari 8-9 peserta didik. Praktikum berjalan lancar, peserta didik antusias dalam mengikuti praktikum. Beberapa kelompok perlu bimbingan dalam memahami tujuan dari pembelajaran tersebut, terutama dalam penyusunan laporan hasil praktikum karena lembar kerja yang diberikan dalam bentuk terbuka, sehingga peserta didik dituntut untuk berfikir dan berkreasi sendiri sesuai tujuan praktikum. Nampak dalam kegiatan tersebut yang paling menonjol adalah kelompok 2, namun secara keseluruhan 3 aspek aktivitas belajar IPA (fisika) yaitu diskusi, kerjasama, dan keaktifan diikuti peserta didik dengan sangat antusias. Diskusi kelompok yang baik pada kelompok 2 dan 5. Kerjasama yang baik terlihat pada kelompok 1, 2 dan 3. Keaktifan yang baik tampak pada kelompok 2 dan 6 . Hasil pengamatan aktivitas belajar IPA (fisika) pada siklus I terdapat 22 peserta didik atau 66,7\% yang mencapai aktivitas belajar berkualifikasi baik.

Data hasil pengamatan hasil belajar IPA (Fisika) terlihat pada hasil ulangan harian dalam bentuk tes tertulis dilakukan pada akhir siklus I untuk mendapatkan data hasil belajar peserta didik. Dari 
hasil tes pada siklus I diperoleh nilai terendah 55, nilai tertinggi 85, dan rerata nilai 71,21. Terdapat 20 peserta didik (60,61\%) memperoleh nilai hasil belajar IPA $\geq 75$ atau tuntas KKM.

\section{Deskripsi Data Siklus II}

Pada siklus II pembelajaran menggunakan KIT sumber tegangan arus searah kelompok kecil. Praktikum berjalan lancar, peserta didik antusias dalam mengikuti praktikum. Beberapa kelompok perlu bimbingan dalam memahami tujuan dari pembelajaran tersebut, terutama dalam penyusunan laporan hasil praktikum karena lembar kerja yang diberikan dalam bentuk terbuka, sehingga peserta didik dituntut untuk berfikir dan berkreasi sendiri sesuai tujuan praktikum. Secara keseluruhan 3 aspek aktivitas belajar IPA (fisika) yaitu diskusi, kerjasama, dan keaktifan diikuti peserta didik dengan sangat antusias. Terdapat 26 peserta didik atau $78,8 \%$ yang mencapai aktivitas belajar berkualifikasi baik.

Data hasil pengamatan hasil belajar IPA (Fisika) berdasarkan ulangan harian dalam bentuk tes tertulis dilakukan pada akhir siklus II untuk mendapatkan data hasil belajar peserta didik. Dari hasil tes pada siklus II diperoleh nilai terendah 60 , nilai tertinggi 95, dan rerata nilai 74,85. Terdapat 25 peserta didik $(75,76 \%)$ memperoleh nilai hasil belajar IPA $\geq 75$ atau tuntas KKM.

\section{Pembahasan}

Permasalahan dalam penelitian ini adalah rendahnya aktivitas dan hasil belajar IPA ( fisika). Hal tersebut karena guru belum menggunakan media yang tepat untuk membantu peserta didik mempelajari materi listrik sehingga siswa menganggap bahwa pelajaran IPA (fisika) sulit, membosankan dan tidak menarik. Perlu pemilihan media yang tepat untuk memecahkan masalah tersebut. Media yang dimaksud adalah KIT listrik. Penelitian tindakan kelas ini terdiri dari 2 siklus. Pada siklus I KIT listrik yang digunakan dengan kelompok besar sedangkan pada siklus II KIT listrik yang digunakan dengan kelompok kecil. Hasil pengamatan menunjukkan bahwa penggunaan KIT listrik ternyata berdampak pada aktivitas 
dan hasil belajar IPA (fisika).

Aktivitas belajar IPA (fisika) diamati pada aspek diskusi, kerjasama, dan keaktifan menunjukkan peningkatan dari kondisi awal, siklus I dan siklus II. Adapun hasil peningkatan aktivitas belajar IPA (fisika) dari siklus awal, siklus I dan siklus II tampak pada tabel berikut:

Tabel 1

Peningkatan aktivitas belajar dari kondisi awal, siklus I dan siklus II

\begin{tabular}{|c|l|c|c|c|}
\hline NO & \multicolumn{1}{|c|}{ Kualifikasi baik } & $\begin{array}{c}\text { Kondisi } \\
\text { awal }\end{array}$ & $\begin{array}{c}\text { Siklus } \\
\text { I }\end{array}$ & $\begin{array}{c}\text { Siklus } \\
\text { II }\end{array}$ \\
\hline 1 & Jumlah peserta didik & 10 & 22 & 26 \\
\hline 2 & Persentase & 30,3 & 66,7 & 78,8 \\
\hline
\end{tabular}

Data tersebut dapat divisualisasikan dengan diagram berikut:

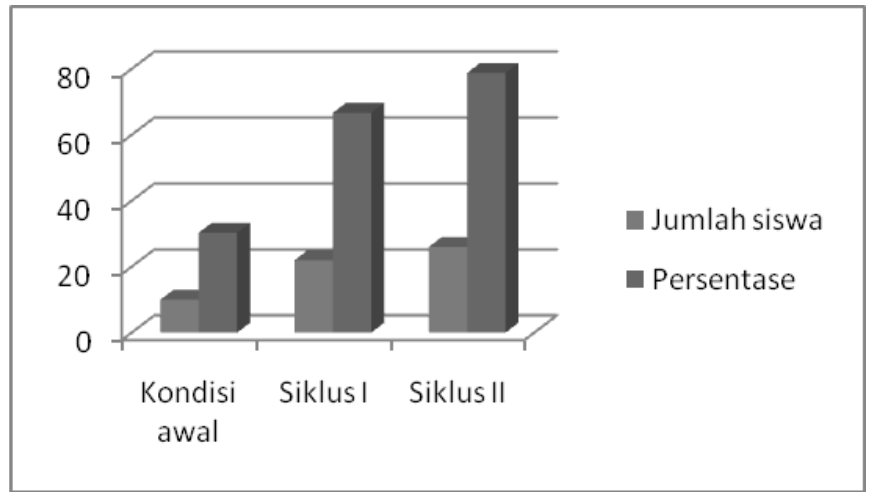

\section{Gambar 3}

\section{Peningkatan aktivitas belajar dari kondisi awal,} siklus I dan siklus II

Grafik di atas menunjukkan adanya peningkatan aktivitas belajar peserta didik, pada kondisi awal 30,3\%, pada siklus I meningkat menjadi $66,7 \%$ dan pada siklus II meningkat menjadi $78,8 \%$. Pada indikator kinerja penelitian, indikator keberhasilan direfleksikan dengan $60 \%$ peserta didik mencapai rerata skor aktivitas belajar lebih besar dari 3,00 (kualifikasi baik) pada 
siklus I dan $70 \%$ peserta didik mencapai rerata skor aktivitas belajar lebih besar dari 3,00 (kualifikasi baik) pada siklus II. Dengan melihat aktivitas belajar maka pada siklus I dan II telah tercapai indikator tersebut. Melalui pengunaan alat peraga KIT listrik dapat meningkatkan aktivitas belajar IPA (fisika) bagi siswa kelas IXF dari kondisi awal 30,3\% menjadi kondisi akhir 78,8\%.

Hasil belajar IPA (fisika) yang diperoleh dari nilai tes tertulis menunjukkan peningkatan dari kondisi awal, siklus I dan siklus II. Peningkatan hasil belajar peserta didik dapat dilihat pada tabel berikut:

Tabel 2

Perbandingan hasil belajar peserta didik

\begin{tabular}{|c|c|c|c|}
\hline & Kondisi awal & Siklus I & Siklus II \\
\hline Tuntas KKM & 12 & 20 & 25 \\
\hline Persentase & 36,36 & 60,61 & 75,76 \\
\hline Rata-rata & 64,85 & 71,51 & 74,85 \\
\hline
\end{tabular}

Data tersebut dapat divisualisasikan dengan diagram berikut:

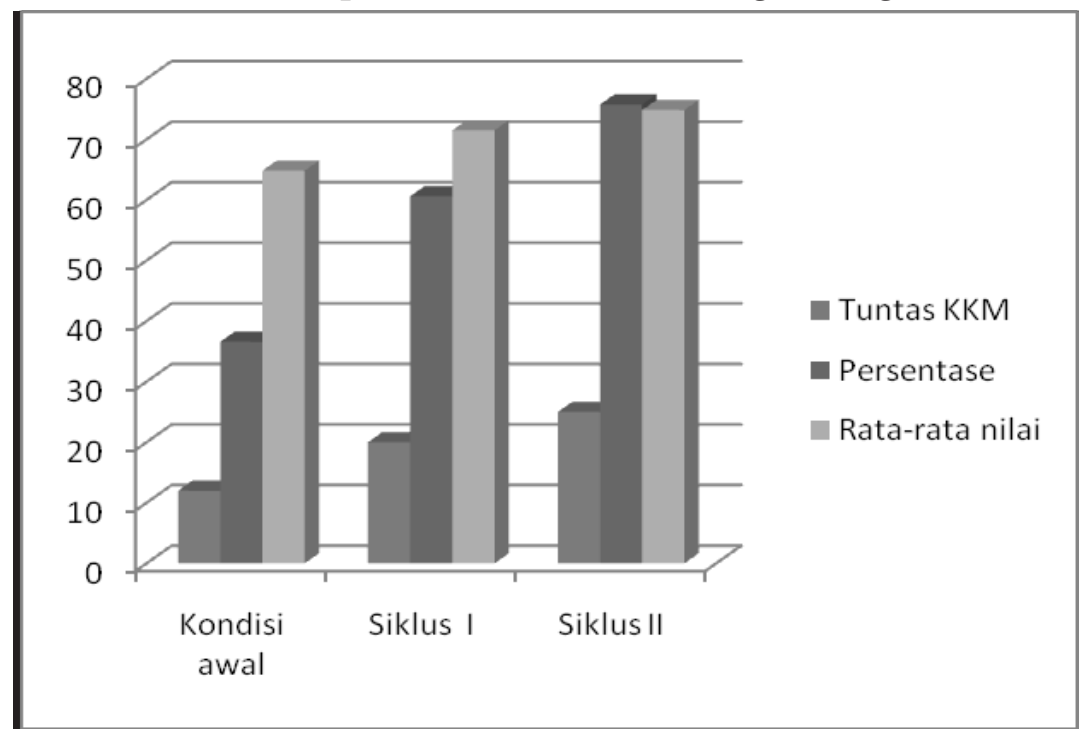

\section{Gambar 4}

Perbandingan hasil belajar peserta didik 
Dari kondisi awal ketuntasan minimalnya mencapai 36,36\%, siklus I ketuntasan naik menjadi 60,61 \% sedangkan siklus II ketuntasan naik menjadi 75,76 \%. Pada indikator kinerja, keberhasilan direfleksikan dengan $60 \%$ peserta didik memperoleh nilai hasil belajar $\geq 75$ pada siklus I dan $70 \%$ peserta didik memperoleh nilai hasil belajar $\geq 75$ pada siklus II. Nilai 75 adalah nilai ketuntasan minimal (KKM). Dengan melihat ketuntasan belajar maka hasil dari siklus I dan siklus II berarti telah mencapai indikator tersebut. Jadi melalui penggunaan alat peraga KIT listrik dapat meningkatkan hasil belajar IPA (fisika) materi listrik dinamis dan materi sumber tegangan arus searah bagi peserta didik kelas IXF SMP Negeri 1 Kaliwungu Kudus dari kondisi awal ketuntasan 36,36\% menjadi kondisi akhir 75,76\%.

\section{Hasil Tindakan}

Berdasarkan perbandingan data kondisi awal, siklus I dan siklus II yang dijabarkan dalam pembahasan dapat disimpulkan tindakan yang dilakukan pada siklus I maupun siklus II membawa peningkatan baik aktivitas belajar maupun hasil belajar. Aktivitas belajar IPA (fisika) mengalami peningkatan dari 30,3\% pada kondisi awal menjadi $78,8 \%$ pada kondisi akhir, berarti meningkat $48,5 \%$. Hasil belajar IPA (fisika) mengalami peningkatan dari rerata 64,85 pada kondisi awal menjadi 74,85 pada kondisi akhir, berarti meningkat 10 . Persentase jumlah peserta didik yang tuntas belajar meningkat dari 36,36\% menjadi 75,76\%, berarti meningkat $39,40 \%$. Dengan demikian dapat disimpulkan bahwa: (a) melalui pemanfaatan alat peraga KIT dapat meningkatkan aktivitas belajar peserta didik yang dari kondisi awal belum memanfaatkan alat peraga KIT ternyata aktivitas belajarnya rendah ke kondisi akhir setelah memanfaatkan alat peraga KIT aktivitas belajarnya tinggi, (b) melalui pemanfaatan alat peraga KIT dapat meningkatkan hasil belajar peserta didik yang dari kondisi awal belum memanfaatkan alat peraga KIT ternyata hasil belajarnya rendah ke kondisi akhir setelah memanfaatkan alat peraga KIT hasil belajarnya tinggi, (c) melalui pemanfaatan alat peraga KIT dapat meningkatkan aktivitas dan hasil belajar fisika. 


\section{Simpulan}

1. Melalui pemanfaatan alat peraga KIT aktivitas belajar fisika materi kelistrikan bagi peserta didik kelas IXF SMP Negeri $1 \mathrm{Ka}-$ liwungu Kudus pada semester 1 tahun 2012/2013 meningkat. Peningkatan aktivitas belajar fisika sebesar $48,5 \%$ dari kondisi awal $30,3 \%$ menjadi $66,7 \%$ pada siklus I dan $78,8 \%$ pada akhir siklus II.

2. Melalui pemanfaatan alat peraga KIT hasil belajar fisika materi kelistrikan bagi peserta didik kelas IXF SMP Negeri $1 \mathrm{Ka}-$ liwungu Kudus pada semester 1 tahun 2012/2013 meningkat. Peningkatan hasil belajar fisika sebesar 39,16\% dari kondisi awal $36,36 \%$ (tuntas $\mathrm{KKM}=12$, rata-rata $=64,85$ ) menjadi $71,51 \%$ (tuntas $\mathrm{KKM}=20$, rata-rata $=71,51$ ) pada siklus I dan 75,76\% (tuntas $\mathrm{KKM}=25$, rata-rata $=74,85$ ) pada akhir siklus II.

3. Melalui pemanfaatan alat peraga KIT aktivitas dan hasil belajar fisika materi kelistrikan bagi peserta didik kelas IXF SMP Negeri 1 Kaliwungu Kudus pada semester 1 tahun 2012/2013 meningkat. 


\section{DAFTAR PUSTAKA}

Arikunto, Suharsimi. 2010. Penelitian Tindakan, Yogyakarta: Aditya Media

Depdiknas. 2006. Standar Kompetensi dan Kompetensi Dasar IPA SMP/MTs. Jakarta: Depdiknas.

Druxes Herbert, 1995. Kompendium Didaktik Fisika. Bandung: PT. Remaja Rosdakarya

Hamalik, O. 2004. Psikologi Belajar dan Mengajar. Bandung: Sinar Baru Algensindo.

Hamruni. 2012. Strategi Pembelajaran. Yogyakarta: Insan Madani

Hindarto, Nathan. 1995. Melalui Pemantapan Pendidikan Fisika Kita Kembangkan Sains dan Teknologi dengan Penuh Tanggung Jawab. Pidato Ilmiah: Lustrum VI IKIP Semarang

Natawijaya, Rochman. 1979, Pembinaan dan Pengembangan Kurikulum Alat Peraga dan Komunikasi Pendidikan. Jakarta: Depdikbud

Sadirman. 2004. Interaksi dan Motivasi Belajar Mengajar. Jakarta: PT Raja Grafindo

Slameto. 2006. Belajar dan Faktor-faktor yang Mempengaruhinya. Jakarta: Rineka Cipta

Subiyantoro. 2009. Penelitian Tindakan Kelas: Edisi Revisi. Semarang: CV. Widya Karya. 